\title{
Media, politics, and climate change : the ASA Task Force report and beyond
}

\section{Stoddart, Mark C.J.}

2017-05-19

Stoddart , M C J , Ylä-Anttila , T \& Tindall , D B 2017 , ' Media, politics, and climate change : the ASA Task Force report and beyond ', Environmental Sociology , vol. 3 , no. 4 , pp. 309-320 . https://doi.org/10.1080/23251042.2017.1329613

http://hdl.handle.net/10138/311258

https://doi.org/10.1080/23251042.2017.1329613

unspecified

acceptedVersion

Downloaded from Helda, University of Helsinki institutional repository.

This is an electronic reprint of the original article.

This reprint may differ from the original in pagination and typographic detail.

Please cite the original version. 
Media, politics, and climate change: The ASA Task Force report and beyond

Mark C.J. Stoddart, Department of Sociology, Memorial University, St. John's, NL, Canada

Tuomas Ylä-Anttila, Department of Social Research; University of Helsinki, Helsinki, Finland

David B. Tindall, Department of Sociology, University of British Columbia, Vancouver, BC, Canada

Corresponding author: Dr. Mark CJ Stoddart, Phone: 1.709.864.8862, Email:

mstoddart@mun.ca

Word count: 8,601

Acknowledgements: We would like to thank Stewart Lockie for his comments throughout the development of this paper. 


\begin{abstract}
This review essay focuses on the American Sociological Association Task Force on Sociology and Global Climate Change final report, Climate Change and Society: Sociological Perspectives. We take the report as a jumping off point to provide an overview of research on climate change in the media sphere and in the political sphere. The political sphere and the media sphere are key sites for the politics of climate change, where the meaning of the causes and consequences of climate change, as well as policy responses for mitigation and adaptation, are contested and negotiated among policy makers, corporate interests, environmental scientists, environmental movements and counter-movements. While there are substantial bodies of research on climate change within both the political and media spheres, less research specifically addresses how the social dynamics of one of these spheres shapes social interaction in the other sphere. Insights into the relationships between these spheres are suggested by the ASA Task Force report, but this area is under-examined in current research. As such, we argue that there is a need for more research that bridges policy-oriented and media-oriented perspectives on climate change.
\end{abstract}

Keywords: climate change; environmental communication; environmental politics; climate politics; environmental movements; climate change denial; environmental sociology 


\section{Media, politics, and climate Change: The ASA Task Force report and beyond}

In her programmatic 2008 article, Constance Lever-Tracy (2008) noted the "strange silence of mainstream sociology" on the issue of climate change, which by then had become a highly visible environmental issue in political and public discourse around the world. While Lever-Tracy's argument downplayed the rich climate change literature that was emerging within environmental sociology by 2008 , her article highlighted that many sociologists outside environmental sociology were largely unaware of this work and didn't see climate change as a key sociological concern.

Jump forward to 2015 and the terrain has changed dramatically. The American Sociological Association, the world's largest national sociology association, convened a Task Force on Sociology and Global Climate Change that included participation by many of the prominent environmental sociologists working in this area. Their final report, Climate Change and Society: Sociological Perspectives, was published by Oxford University Press (Dunlap and Brulle 2015). The first thing to note is that the ASA task force report is significant accomplishment within the field of Sociology. It synthesizes a remarkable body of research on the sociology of climate change. It also demonstrates that the ASA and "mainstream sociology" have recognized the social importance of climate change and the vital role that sociologists are playing in better understanding the social-environmental dynamics of this issue.

It appears the work represented by the report is also gaining public visibility. The "web of denial" campaign of speeches by U.S. Democrat Senators provided a close examination of the climate denial movement and have foregrounded the research of several authors of the report (Richardson 2016). Task force co-chair Riley Dunlap was also appointed one of fifteen members 
of the U.S. Advisory Committee for the Sustained National Climate Assessment

(GlobalChange.gov 2016). As such, the ASA task force report is both a notable accomplishment in its own right, and a key event in the academic and public mainstreaming of the sociology of climate change, and environmental sociology more broadly. The resonance of the report in the social context of the latter days of the Obama administration demonstrates the potential policy relevance and applied value of solid, rigorous research in environmental sociology. While the report is understandably US-focused and thus limited in its attention to international research on the sociology of climate change, it may serve as an aspirational model for sociologists elsewhere.

In this essay, we do not attempt to provide a comprehensive overview of the report, which has a wide focus and touches on a broad range of research topics within the sociology of climate change. Instead, we use the Task Force report, Climate Change and Society: Sociological Perspectives, as a jumping off point to focus on the climate change in the media sphere and in the political sphere. We have set the scope of our review in this way because these are particularly important dimensions of the sociology of climate change. The political sphere and the media sphere are key sites for the "cultural politics of climate change" (Crow and Boykoff 2014), where the meaning of the causes and consequences of climate change, as well as policy responses for mitigation and adaptation, are contested and negotiated among policy makers, corporate interests, environmental scientists, environmental movements and counter-movements, and other key actors. Furthermore, as Brulle, Carmichael, and Jenkins (2012) note, public opinion about climate change is largely shaped by the public discourse of political and social movement elites, which is often encountered through mass media coverage of the issue. There are substantial bodies of research on climate change within both the political and media spheres. 
However, there is much less research - in the Task Force Report and beyond - that explicitly addresses how the social dynamics of one of these spheres shapes social interaction in the other sphere. For example, how does power and influence within the political field translate into influence within the media field, and vice versa? What influence do news organizations and journalists have within the political sphere? Or, drawing on Manuel Castells' (2009) terminology, who are the key "switchers" that serve to bridge media discourse networks and policy networks outside the media sphere? How do these switchers leverage their power in one field to gain access and visibility for their claims in the other field? These questions are suggested by work of the ASA Task Force on Sociology and Global Climate Change, but they are questions that are largely unanswered in current research. Through our review, we argue that there is a need for more research that bridges policy-oriented and media-oriented perspectives on climate change.

The rest of this essay unfolds as follows. In the next section, we review research on the politics of climate change in the media sphere. Then, we will review research on climate change in the political sphere. We follow this with a discussion of the relatively limited body of research that attends to relationships across the political and media spheres. Throughout these sections, we begin with a discussion of the ASA task force report, then extend this to include a larger international scope of research in both of these areas. We agree with the Task Force that a sociological perspective is particularly well-equipped to analyse how climate change is intertwined with "social structure and institutions, cultural values and beliefs, and social practices" (Brulle and Dunlap 2015, 16). While our review focuses primarily on that insights from environmental sociological research, we also draw on work from political science, communications and other environmental social sciences, as the boundaries between these 
different disciplines often overlap. Finally, we conclude the essay with suggestions for future research on the sociology of climate change that can build upon the remarkable work of the ASA Task Force.

\section{Climate Change in the media sphere}

The mass media are a key venue where the politics of climate change play out. Through news coverage of climate change, politicians, environmentalists, think tanks, climate scientists and denialists engage in public debate and make claims about the causes, consequences and preferred solutions to climate change. Media coverage is one of the key ways in which members of the public pick up the cues from political and social movement actors that shape public opinion about this issue (Brulle, Carmichael, and Jenkins 2012; Schafer and Schlichting 2015; Zhao, Rolfe-Redding, and Kotcher, 2016). In their chapter in the Task Force Report, EhrhardtMartinez et al. (2015) similarly note the key importance of media coverage, along with social networks and personal experience, in shaping public opinion about climate change and willingness to become involved in environmental movements around this issue.

The ASA task force report does not devote a great deal of attention to analyzing climate change in the media sphere. It does, however, discuss the exceptional success of the climate change denial movement in the US in shaping public debate (Dunlap and McCright, 2015). In most other countries the scientific consensus on the reality and severity of climate change is accepted in the media debate, and coverage is driven by the global political process centered around the United Nations. In the US, however, the denial movement has been successful at "manufacturing controversy," or developing a mass media narrative that climate science is contested and uncertain among scientists. This has been achieved through networks of fossil fuel 
companies, conservative think-tanks, and environmental counter-movements, whose claims have been amplified by conservative media outlets. The success of the counter-movement means that the U.S. media sphere often works as a space of "anti-reflexivity" that protects the "industrial capitalist system from widespread scientific, political, and public acknowledgement of the system's unintended and unanticipated consequences, such as climate change" (Dunlap and McCright 2015, 321).

Dunlap and McCright highlight how U.S. media coverage enacts climate change politics in a way that gives more visibility to sources from the climate denial movement than would seem justified based on their standing in the climate science field. Building on journalistic norms of achieving "balance" by positioning competing viewpoints against each other, the U.S. news narratives often produce a "false balance" that pits climate "believers" against "denialists" and gives the media audiences the impression that the climate change is more controversial and contested than is the case within scientific fields of climate knowledge production. This argument is supported by findings from other key research in the area (Boykoff 2011, 2013; Freudenburg and Muselli 2010, 2013).

While not entirely unique to the US, the denialist movement there is much stronger than anywhere else, mainly due to strong industry funding, and journalists seem to be buying their claims more than anywhere else. The journal Environmental Communication has published overviews and meta-analyses of research in this area, which conclude that though analyses of climate change media coverage have proliferated, this work tends to have a North American and European geographical bias and that this often excludes analyses of media spheres in societies that are most vulnerable to the impacts of climate change (Olausson and Berglez 2014; Schafer and Schlichting 2014). 
Comparative research on climate change media coverage often looks at the U.S. in comparison to countries in Europe or elsewhere. In general, this work finds the "false balance" mass media narrative of climate change is much more prevalent in the U.S. than elsewhere. (Brossard, Shanahan, and McComas 2004; Dispensa and Brulle 2003; Evans 2016; Grundmann 2007). While the climate denial movement has been most successful at influencing the U.S. media sphere, Dunlap and McCright (2015) note that they have been able to shape media narratives in other Anglophone countries (including the U.K., Canada, and Australia) to a larger degree than other parts of the world. However, as other research illustrates, this has not necessarily translated into media coverage that simply mimics the U.S. format of false balance, where climate denialists are routinely positioned against the claims of mainstream climate science. For example, Neil Gavin and his co-authors' work on media coverage in the UK demonstrated that until 2006 climate change received relatively little coverage compared with other issues, but that the activities of the IPCC might drive an increase in the volume and quality of media attention to the issue (Gavin 2009). However, contrary to these expectations, a followup article that extends this analysis to 2009 finds that climate denialist and contrarian voices were gaining ongoing access to U.K. media coverage, taking particular advantage of the "climategate" scandal (Gavin and Marshall 2011). Gavin and Marshall note that the contrarian position is also amplified in media that allow online user responses, and the public opinion effects of media exposure for the contrarian position appear to be an increased confusion about the seriousness of climate change among the British public. A more recent article by Painter and Gavin (2016) further extends this analysis to 2011 and finds that the visibility of climate denialists in the U.K. media has generally increased, though this increasingly takes the form of "impact skepticism," or questioning the severity of climate change impacts and need for a 
political response, rather than the more traditional forms of "trend skepticism," which denies evidence that climate change is occurring, or "attribution skepticism," which acknowledges warming trends but denies human causation (Painter and Gavin 2016, 436).

Research on media coverage in Canada finds that climate denialist opinions do appear and U.S.-based news sources are prevalent in Canadian climate change coverage. However, Canadian national news outlets do not adhere to the U.S. model of providing an "'experts in conflict' narrative" (Young and Dugas 2011, 16). Young and Dugas (2012) also find substantial differences between media outlets in English and French Canada, with French media narratives more likely to focus on political conflict and social justice dimensions of climate change, connecting climate change to the notion of Quebec Vert (green Quebec), while providing less visibility for climate denialist discourse.

International research further demonstrates that social context makes a significant difference to the type of coverage climate change gets in the media. For example, Grundmann's (2007) comparative research on U.S. and German media coverage shows that while U.S. media coverage focuses on scientific uncertainty, German media coverage often conveys a discourse of "climate catastrophe" and that scientific evidence for the negative impacts of climate change is sufficient to drive action. In his analysis of the strategies Swedish journalists use to translate the complex, abstract issue of climate change into news conventions, Berglez (2011) notes that the Swedish media discourse is predominantly one that accepts the scientific consensus that anthropogenic climate change is real and serious, and positions the government and citizens as having an important role to play in addressing the issue. By contrast, Billett’s (2009) study of India shows that media largely accept the scientific consensus on climate change and convey the significant impacts of climate change on the country. However, Indian media adopt a North- 
South framework for interpreting climate change responsibility and vulnerability, typically positioning climate change as the result of U.S. and other Northern industrialized counties, who are seen as the key actors that should take responsibility for addressing the issue.

International media research further shows that media visibility for climate change is often driven by events occurring within global institutions, such as IPCC reports and UNFCCC meetings, as well as domestic political debate and conflict over the issue (Eide and Kunelius 2012; Schmidt, Ivanova, and Schafer 2013). In other words, media coverage is not necessarily driven by the ecological dimensions of climate change. Instead, the issue receives more coverage when there is heightened activity within climate politics. For example, Broadbent et al. (2016) draw on data from across 17 national case studies and observe that media coverage across most of these societies peaked in 2007 in response to a constellation of events that included the release of the Al Gore film, An Inconvenient Truth, the release of the Fourth IPCC Assessment Report, and the release of the Stern Report in the U.K. They further note that the main lines of contention that structure the "global field" of media discourse are the "validity of climate science, scale of ecological risk, scale of climate politics, and support for mitigation policy," which also reflects media interest in the political dimensions of climate change (Broadbent et al. 2016, p. 12). From this work, we see that political processes and critical events are often what makes climate change newsworthy and drives media coverage of climate science.

The ASA Task Force report highlights how the media sphere works as a space for contesting the mainstream consensus position of climate science that climate change is serious, human-caused and requires a significant political response. It provides insight into the ways in which climate change is framed for bystander audiences in ways that directly and indirectly shape public opinion, which can then legitimate political opposition to action on climate change. 
As our review illustrates, however, the dominant media discourse in the U.S. is not necessarily representative of media discourse internationally, where media framing of climate change is more likely to accept the scientific consensus on the reality and severity of climate change. Instead, the politics of climate change in countries outside the U.S. is more often structured by debate over what policy responses are most appropriate or desirable, the economic dimensions of climate change impacts and responses, or questions of which countries should assume the greatest responsibility and take the lead in addressing climate change. This points to the importance of adopting a broader international scope in our understanding of how climate change debate plays out in the media sphere.

\section{Climate change in the political sphere}

As research on the politics of climate change from environmental governance (Bulkeley and Betsill 2013; Rootes, Zito, and Barry 2012; Stevenson and Dryzek 2014) and climate policy networks (Compston 2009; Fisher, Leifeld, and Iwaki 2013; Ingold and Fischer 2014) standpoints highlights, climate policy debate is not only the purview of politicians and national governments. Rather, as in media coverage of climate change, climate change in the political sphere also involves interaction and conflict among a range of actors that includes governments and opposition parties, scientists, corporate interests and think-tanks, social movements and counter-movements. As an issue that has causes and impacts that cross ecological and political scales, climate change also increasingly involves interactions and negotiations across multiple political spheres that operate at different scales, including municipalities, state or provincial governments, federal governments, as well as multi-lateral agencies. Francesch-Huidobro characterizes this as the two types of processes that increasingly characterize climate 
governance: a "vertical" dimension that connects different political scales (local, regional, national and international), and a "horizontal" dimension that connects state and non-state actors (Francesch-Huidobro 2012).

Several chapters in the ASA Task Force report on climate change examine climate change in the political sphere. In their Introduction, for example, Brulle and Dunlap (2015) note that the research that has entered the U.S. policy sphere has thus far been dominated by the physical sciences. Insofar as social scientific perspectives have been included, it has tended to be through the individualized perspectives of economics and psychologists. This reinforces a "postpolitical" approach to climate change, which sees the issue as "a technical and managerial problem to be handled by developing and applying the best scientific information in a consensual fashion - albeit with the participation of individual citizens and decision-makers who will become more informed and engaged in part via the work of social scientists" (Dunlap and Brulle, 2015, 415). This is consistent with the much of the IPCC emphasis on resource efficiency and technological solutions to climate change (Ehrhardt-Martinez et al. 2015). However, this postpolitical approach produces an understanding of climate change as an "abstraction that occurs 'everywhere and nowhere'" that brackets out the significant social inequalities in which groups are most responsible for and vulnerable to climate change (Harlan et al. 2015, 146). What is lost by the absence of a sociological perspective within the policy sphere is a deeper understanding of how climate change is "embedded in social structure and institutions, cultural values and beliefs, and social practices," and that political responses need to account for these social-cultural contexts and their related power dynamics (Brulle and Dunlap 2015, 16).

However, while one tendency is to treat climate change as a "post-political" issue, a major countervailing tendency has been the increasing political polarization of views on the reality and 
severity of climate change (Shwom et al. 2015). Through Bulkeley's Australian research, we see that climate change policy networks are not static, but through time may become realigned around new understandings or political consensus (Bulkeley 2000, 2014). Conversely, while early political discussions about climate change were not structured along partisan lines, climate change belief or denial in the U.S. has increasingly become tied to collective identity and political ideology (McCright and Dunlap 2011). Democrat political party affiliation has become increasingly tied to adherence to the scientific consensus position that climate change is real, human-caused, serious in its consequences and deserves a significant response. By contrast, the climate denialist position that refuses some or all of axioms of the scientific consensus has become increasingly linked to Republican political party affiliation. The adoption of the denialist position by President Trump and his supporters as a part of their identity politics during the electoral campaign is likely to have further increased this polarization.

This polarization has been driven to a large extent by the success of the industry-funded think-tanks and other organizations, which have pursued a systematic campaign denying the findings of climate science. Jasny, Waggle, and Fisher (2015) show that there is also an "echo chamber" effect, resulting from the clustering of communication networks among politicians and scientists that further reinforces political polarization. This polarization has had significant impacts on U.S. policy responses to climate change, leading to policy paralysis at the national level. By contrast, more significant policy responses to climate change often emerge at the subnational scale among particular states and municipalities (Tompkins and Amundsen 2008). While meaningful action can be taken within subnational political spheres in the U.S., they lack the power to have much influence within multilateral sites of global climate change debate and policy-making. 
In their chapter in the Task Force Report, Perrow and Pulver (2015) focus on the role of private sector businesses, as particularly important non-state actors, in climate politics. As they note, market actors have an interest in political interpretations of climate change that focuses on voluntary actions by individual companies, rather than questioning the profit-seeking behaviour that is foundational to corporate capitalism as a driver of climate change. Market actors use various strategies to intervene in climate politics, including the "structural power" of "maintaining economic growth," the "instrumental power" of "financial support, lobbying activities, and social and business connections" and the "discursive power" of issue framing "through advertising and other reputation-building activities" (Perrow and Pulver 2015, 69). In the U.S. context, the corporate sector further benefits from the polarization of public opinion, manufactured by the denialist movement. By contrast, in European Union climate policy, businesses have played a more collaborative role. They have helped direct policy networks towards an emphasis on "renewable energy directives, carbon capture and storage, and energy efficiency for buildings," as well as the EU Emissions Trading Scheme (Ibid., 75). However, this does not necessarily reflect pro-environmental leadership on the part of corporate actors. Rather, it may reflect a strategic response to navigating an emerging political landscape in which the EU was showing signs of moving towards stronger pro-climate policies.

The ASA Task Force synthesizes a great deal of valuable research on the social dynamics of climate governance in the U.S. setting, but devotes less attention to cross-national comparisons or the role of international organizations in climate policy making. EhrhardtMartinez et al. (2015) do note that the United Nations has served as a space for international debate and negotiation on climate policy, adopting the "goal of persuading self-interested actors to see the longer-term view and to act in accordance with the collective good" (Ehrhardt- 
Martinez et al. 2015, 219). US engagement in the UN climate change policy process has oscillated according to which party holds power. The Democrat Clinton administration negotiated the US into the Kyoto protocol in 1997, the Republican Bush pulled the country out of it in 2001. Obama signed the Paris agreement in 2015, and Trump has announced he intends to pull out.

The Task Force chapter by Harlan et al. (2015) also adopts an international focus. Working from a climate justice and world systems theory perspective, they emphasize societallevel inequalities in the causes of climate change, which have largely been driven by the affluent countries of the global North, and the social groups that are most vulnerable to the negative impacts of climate change, which are often in the global South. This perspective helps us better understand many of the tensions that work against international collaboration and agreement on climate change responses, as national representatives often work from "different interpretations of equitable allowances for emissions" (Harlan et al. 2015, 143). While these chapters draw attention to international dynamics of climate politics and the role of multilateral agencies like the UN and IPCC, these issues generally draw less attention in the Task Force Report than examinations of US climate politics.

For some authors, such as Beck (2015) and Urry (2011), the global scale of climate change has the possibility to lead to a more "cosmopolitan" environmental politics that shifts us away from a nation-state lens of viewing environmental problems. Urry argues that the "science, politics and media" of climate change produce "new kinds of mobility, openness, reflexivity, plurality and public spheres" that help to produce a more cosmopolitan view of the world (Urry 2011, 102). For Beck, climate cosmopolitanism involves "a greater focus on decision-makers and the consequences of their decisions for others across space and time" beyond national 
boundaries, which would incorporate international and intergenerational climate justice concerns (Beck 2015, 76). Beck offers the term "emancipatory catastrophism" to think about how seeing the catastrophic impacts of climate change unfold through increasingly extreme storms, sea-level rise, and droughts around the world may help shift the world towards emancipatory, systemic transformations of "social changes modes of thought, of lifestyles and consumer habits, of law, economy, science and politics" (Beck 2015, 79).

This optimistic vision of a more cosmopolitan climate politics contrasts starkly with other research on international climate policy negotiation that adopts a world systems perspective. The climate justice perspective, for example, emphasizes that international climate policy unfolds against histories of European colonization and empire. The substantial and durable power inequalities between the developed countries of the global north and the less developed countries of the global south help produce factions that align around very different interpretations of who is most responsible for addressing climate change and the types of political responses that are appropriate (Roberts and Parks 2007). As MacGregor (2010) further notes, vulnerability to climate change is not only shaped by the macrosocial location of particular societies within the world system, but is also gendered, with women often bearing a disproportionate vulnerability to the harms of climate change, while often having less power to participate in the spaces of climate policy debate and decision-making. While the climate justice perspective is taken up in the ASA Task Force report, feminist analyses of climate justice are less visible and might be further developed.

Drawing from international research provides further insight into the ways in which climate politics is shaped by different social contexts. Tompkins and Amundsen (2008) examine how climate discourse from the UN Framework Convention on Climate Change was taken up in 
the European Union and the United States. They note that there is an unresolved friction between the more globalist environmental governance orientation, which is more characteristic of the EU, and the market-oriented standpoint of the US. This friction hindered the diffusion of UNFCC climate discourse into national-level policy making and has often made local-level political spheres a more promising site for climate action. Elsewhere, Jordan and Huitema (2014) argue that the "pledge and review" structure of climate governance adopted by the UN effectively means that national governments often remain the main policy actors in climate governance, despite the discourse of internationalism.

Cities and local governments and campaigns have been seen as potential sources of climate change action, whether through engaging with other actors in multi-scalar climate governance or through encouraging new forms of environmental citizenship (Betsill and Bulkeley 2006; Slocum 2004). This is concerns especially initiatives on adaptation to (rather than mitigation of) climate change. Wejs et al. (2014) examine local climate adaptation programs in Denmark and Norway, where there are weak national-level frameworks or supports for these programs. In this context, the success of climate adaption depends largely on the work of key leaders and issue entrepreneurs. Similarly, Bauer and Steurer (2014) compare local and regional partnerships for climate change adaptation in Canada and the United Kingdom. Their results provide two particularly significant insights into climate politics. First, they argue that local or regional networks can create policy innovations that "scale up" the vertical dimension of climate governance to shape national climate policy. Second, the Canadian initiatives, which were more government led and better resourced than in the UK, were able to implement climate adaptation projects more quickly, but with less longevity. By contrast, the more grassroots, less government-driven initiatives, were less immediately effective, but were characterized by greater 
longevity. This research points to the value of attending to the ways in which policy innovation may diffuse either "upwards" or "downwards," in terms of the vertical dimension of climate governance. It also suggests there may an optimum balance between state direction and resources, and participation by non-state actors in terms of the horizontal dimension of climate governance.

Finally, research that focuses on issues of how climate change intersects with issues of Arctic sovereignty highlights how messy the intersecting scales of political jurisdiction and climate governance can be when we move beyond a national focus on climate politics (Dodds 2010; Shadian 2014). The most recent IPCC assessment report asserts that the Arctic is already seeing severe impacts of climate change, such as melting sea ice, increasingly long ice-free seasons in the Arctic ocean, shifting ranges of vegetation, animals, birds and insects, and melting permafrost. These rapid shifts are already having significant negative impacts on northern ecologies and northern communities. However, responses to climate change in the north cut across the national political spheres of the eight circumpolar countries (the United States, Canada, Norway, Sweden, Finland, Russia, Denmark and Iceland). Accordingly, the issue is on the agenda of the multilateral Arctic Council formed by these countries. Transnational civil society organizations representing the indigenous populations of the circumpolar countries, such as the Inuit Circumpolar Council and the Saami Council have also taken up arctic climate change as a significant issue, and are involved in the deliberations of the Arctic Council (Shadian 2014). Overall, the Arctic offers perhaps one of the starkest examples of complexity of multi-scale climate governance, as it raises questions of climate responsibility, vulnerability and capacity to respond that cut across local (often predominantly Indigenous) communities, state or territorial governments (including Alaska), multiple national governments (including the U.S.), and 
international organizations including the UN, Arctic Council, and Inuit Circumpolar Council.

With the predominantly national-level focus of the ASA Task Force report, questions about how the governance issues that arise from such multi-scale complexities might be addressed are largely left outside the scope of the report and remain an important research area to explore further.

\section{Connecting the media sphere and the political sphere}

Climate change debate plays out in the political sphere, in the multiple spaces of municipal, regional, national and international policy making, as well as in the mass media. Some authors, perhaps most notably Castells (2009), argue that media power is key to political influence and efficacy, but rarely offer systematic evidence to support this claim. On the other hand, research on policy networks often presumes (either explicitly or implicitly) that the political sphere is the locus of power and that media coverage is an accurate representation of political debate, or else is a superficial epiphenomenon of policy-making. A great deal of work focuses on the social dimensions of climate change in either one or the other of these settings. However, much less research examines how visibility, influence and power translate across the mass media and political spheres, even though climate change is an ideal subject for examining these questions. A few chapters of the Task Force Report touch on these questions, and offer pieces of insight into the relationships between the media and political fields of debate and contestation over climate change impacts and responses.

Returning to Dunlap and McCright's (2015) chapter on the climate denial movement, their main focus is on the success of the climate denial movement at influencing media and public discourse. However, they also touch on the success of the movement at using media to 
make climate denial discourse a key part of conservative and Republican political identity. As they write, "Another essential component of the denial countermovement is the conservative media ... For the past quarter-century, key outlets for climate change denial have been conservative newspapers ... magazines ... talk radio ... television ... and prominent syndicated columnists and personalities ..." (Dunlap and McCright, 2015, 316). This media work by the denial movement has greatly contributed to the bipartisan polarization of the U.S. political sphere on any discussion of climate change responsibility, impacts, or responses.

Caniglia, Brulle, and Szasz (2015) primarily focus on an examination of U.S. environmental movements and the dominant discourses they use to engage in climate change debate. They argue that the U.S. climate change movement can be conceptualized as a mix of inside-insiders that adopt a more deliberative approach (such as World Wildlife Fund), insideoutsiders that are large, well-established organizations that adopt a more confrontational approach (such as Greenpeace), and outside-outsiders that tend to have a more grassroots orientation and work at the peripheries of established political networks (such as climate justice movements). These three components of the movement draw on discourses of green governmentality, which emphasizes scientific expertise and building new global policy responses; ecological modernization, which emphasizes technological responses and promoting sustainable development through existing governance processes; and civic environmentalism, which offers more radical environmental and social justice critiques of dominant approaches to climate change. Caniglia et al. note that those that articulate an ecological modernization perspective have been most successful at gaining access to both U.S. media coverage and policy debate. This has the effect of making an ecological modernization discourse appear as the main voice of the environmental movement in media coverage and policy debate, while limiting the 
visibility of civic environmentalism perspectives, or groups that are more strongly aligned with a climate justice perspective, within both media and political spheres.

In their chapter on climate change mitigation, Ehrhardt-Martinez et al. (2015) also note the influence of the media in relation to climate politics. They write that environmental "movement mobilization also requires an integration of information from three different sources in order to gain traction - media, direct experience, and personal networks" (Ehrhardt-Martinez et al. 2015, 209). However, the media are treated in passing as one of several factors that might drive social movement recruitment and activism, but is not discussed in relation to how media visibility may or may not be related to political efficacy in debates over mitigation. By contrast Hestres' (2015) research focuses on new forms of digital media and uses interview data to look how social media is used to mobilize citizen engagement in climate politics. Hestres finds that most of the media-work by environmental organizations focuses on segments of the public that are either "alarmed" or "concerned" about climate change, but not yet turning this into action in the political sphere. Similar to Caniglia, Brulle, and Szasz's (2015) research, discussed above, Hestres finds a split among environmental organizations that relates to how they conceptualize social change. Groups whose theory of change emphasizes policy and scientific expertise use social media to promote low-cost, less participatory forms of citizen engagement in climate politics. By contrast, groups whose theory of change emphasizes the role of widespread, grassroots mobilization by citizens use social media to promote more engaged, participatory forms of activism within the political sphere.

Moving beyond the Task Force report, other research also helps us to better understand how climate change debate and decision-making works across political and media spheres. For example, Brulle, Carmichael, and Jenkins (2012) draw on U.S. survey data to look at key 
influences on public opinion about climate change. They find that the most important factor is messaging from political elites, including NGO organizations as well as government, but that media coverage has an important indirect influence on public opinion as this is where members of the public often encounter cues from politicians and environmental movements and countermovements.

In their analysis of climate politics in Peru, Takahashi and Meisner (2014) find that politicians are often attentive to mass media coverage of climate change, as it is seen as a key factor that influences public opinion on the issue. Despite the proliferation of new media and online news, they find that in the Peruvian context newspapers, as well as radio, continue to be a significant influence on politicians`views and actions on climate change. In the context of German climate policy networks, Jost and Jacob (2004) also highlight the connections between media and the political sphere. They note that environmental groups are often incorporated into climate policy networks, but in ways that their political efficacy is limited. However, as their research demonstrates, environmental groups that are successful at gaining media visibility are able to leverage this into greater influence and efficacy within policy networks.

Hadden's (2015) research focuses on the networks of social movement organizations and protesters that mobilized around the 2009 Copenhagen Conference of the Parties (COP) climate meetings. She notes that these COP meetings were marked by especially high levels of social movement mobilization that included a broad range of groups, protest tactics and ways of framing the issue. The movement adopted the concept of climate justice as a discursive strategy that could bridge the diverse range of social movement actors at the summit and which could also be conveyed to policy-makers and publics through the media. As she notes, groups like the Climate Action Network also engaged in theatrical forms of protest were staged to gain media 
coverage. While the Copenhagen COP meetings were significant as a protest event, the policy outcomes were seen as disappointing by many observers, and internal divisions became apparent within the climate change movement. Nevertheless, Hadden notes that “... is notable that even though the use of 'climate justice' as a specific phrase has disappeared, states are paying more attention to broader equity and justice issues" (Hadden, 2015, 154). Through this research, we see how protests at the Copenhagen summit, which were amplified by media coverage, were effective at creating a lasting change in the culture of international policy debate by raising the visibility of climate justice discourse.

Finally, the multiple country comparative COMPON (Comparing Climate Change Policy Networks) project is also promising for helping us better understand the social dynamics of climate change across mass media and political spheres (Broadbent et al. 2016; Broadbent et al. 2013). This project has case study teams working in 19 societies, mostly located in North America, Europe and East Asia. The project uses both media data and policy network data to examine which actors are included and have influence and power within climate policy networks. To date, these teams have published analyses of media data from the project, or else on policy network data from the project, which have been based either on single national case studies or on cross-national comparisons (a full list of project publications is available at: http://compon.org/content/publications). Thus far, the COMPON project has not generated relational analyses across the media and political fields, though project teams are collecting data that could make such comparisons feasible in the future.

\section{Conclusion}


Taking the ASA Task Force report on climate change as our starting point, we have illustrated that environmental sociologists have collectively produced a solid and growing knowledge base about the politics of climate change within both the mass media spheres and in the spheres of policy networks and environmental governance. One of the challenges is to translate this knowledge so that it gains greater significance beyond our discipline and outside academia. Applied sociology and public sociology certainly have a role to play connecting an environmental sociological perspective to a range of settings, including policy-making and climate governance, or the work of NGOs and think-tanks. Particularly in the context of the 2016 U.S. election, where it has become popular in the media to claim that we are entering a "postfact" political landscape, it is important for climate scientists and social scientists to remain engaged in public and policy debate. The Trump election may represent a narrowing of the political opportunity structure for social movements and concerned climate scientists at the national level, as climate denialists appear to be gaining power within the new U.S. federal government. However, there may yet be valuable strategic opportunities for public engagement at the state or local level, as well as at the international level.

Our review identifies two particular areas we believe deserve further research. First, a great deal of work examines climate change in either the media spheres or political spheres. However, less work adopts a more relational focus on how the politics of climate change works across these fields (see Figure 1). In the absence of research that specifically examines the flow of influence and power across the media sphere and political sphere, researchers are often left to make inferences and assumptions about these relationships. As such, future research on the politics of climate change would benefit from a greater focus on how the social dynamics of power and influence, information and resources play out across these key fields where the social 
meanings of climate change are contested, and political responses to the issue are debated. A focus on the intersections of these fields may help us better understand how social dynamics of political power, policy-making, and media visibility may influence each other. Such research also has potential to produce results that are significant not only to sociology of climate change, but to political sociology more generally.

\section{[FIGURE 1 ABOUT HERE]}

Second, the focus of this knowledge base over-represents more affluent and overdeveloped societies in North America, the U.K., western and northern Europe, Australia and New Zealand, and East Asia. By contrast, we believe there is room for much more work that examines how the politics of climate change plays out in other regions of the world, including societies in Africa, Latin America, South Asia, and the Middle East. One thing that becomes clear from comparing the largely U.S.-based Task Force report and research that focuses outside the U.S. is the heterogeneity of political and media fields in relation to climate change. In particular, the politicization and polarization of the political and media fields, as well as the power of the climate denial movement to serve as what Castells (2009) terms a "switcher" between these fields, is most pronounced in the United States. Increasing the breadth and depth of comparative inquiry will help us further understand the heterogeneity of climate change media coverage and policy networks, including the conditions under which the US model of climate change politics is taken up or more successfully resisted.

Cross-national comparative inquiry would also benefit from being more attentive to the role of international organizations, including the United Nations and IPCC, but also international 
NGOs like the Inuit Circumpolar Council, who represent non-state interests across national boundaries. A greater focus on these organizations may help us better understand how interactions between sub-national, national and international political actors shape public discourse in the media and political spheres in different social contexts. If climate change has the potential to generate a more "cosmopolitan" environmental politics, as optimistically suggested by Beck (2015) or Urry (2011), to what degree is this shaped by the intervention of international organizations in national or regional political and media spheres?

\section{References}

Bauer, Anja, and Reinhard Steurer. 2014. "Innovation in Climate Adaptation Policy: Are Regional Partnerships Catalysts or Talking Shops?" Environmental Politics 23 (5): 818838.

Beck, Ulrich. 2015. "Emancipatory Catastrophism: What Does it Mean to Climate Change and Risk Society?" Current Sociology 63 (1): 75-88.

Berglez, Peter. 2011. "Inside, Outside, and Beyond Media Logic: Journalistic Creativity in Climate Reporting." Media, Culture \& Society 33 (3): 449-465.

Betsill, Michele M., and Harriet Bulkeley. 2006. "Cities and the Multilevel Governance of Global Climate Change." Global Governance 12 (2): 141-159.

Billett, Simon. 2009. "Dividing Climate Change: Global Warming in the Indian Mass Media." Climatic Change 99 (1-2): 1-16.

Boykoff, Maxwell T. 2011. Who Speaks for the Climate? Making Sense of Media Reporting on Climate Change. Cambridge: Cambridge University Press.

Boykoff, Maxwell T. 2013. "Public Enemy No. 1? Understanding Media Representations of 
Outlier Views on Climate Change." American Behavioral Scientist 57 (6): 796-817.

Broadbent, Jeffrey, John Sonnett, Iosef Botetzagias, Marcus Carson, Anabela Carvalho, Yu-Ju

Chien, Christopher Edling, et al. 2016. "Conflicting Climate Change Frames in a Global

Field of Media Discourse." Socius 2:1-17. doi: 10.1177/2378023116670660.

Broadbent, Jeffrey, Sun-Jin Yun, Dowan Ku, Kazuhiro Ikeda, Keiichi Satoh, Sony Pellissery, Pradip Swarnarkar, Tze-Luen Lin, Ho-Ching Lee, and Jun Jin. 2013. "Asian Societies and Climate Change: The Variable Diffusion of Global Norms." Globality Studies Journal 32: 1-24.

Brossard, Dominique, James Shanahan, and Katherine McComas. 2004. "Are Issue-Cycles Culturally Constructed? A Comparison of French and American Coverage of Global Climate Change." Mass Communication \& Society 7 (3): 359-377.

Brulle, Robert J., Jason Carmichael, and J. Craig Jenkins. 2012. "Shifting Public Opinion on Climate Change: An Empirical Assessment of Factors Influencing Concern over Climate Change in the U.S., 2002-2010." Climatic Change 114 (2): 169-188.

Brulle, Robert J., and Riley E. Dunlap. 2015. "Sociology and Global Climate Change:

Introduction." In Climate Change and Society: Sociological Perspectives, edited by Riley E. Dunlap and Robert J. Brulle, 1-31. New York: Oxford University Press.

Bulkeley, Harriet. 2000. "Discourse Coalitions and the Australian Climate Change Policy Network." Environment and Planning C: Government and Policy 18 (6): 727-748.

Bulkeley, Harriet. 2014. "Revisiting ... Discourse Coalitions and the Australian Climate Change Policy Network." Environment and Planning C: Government and Policy 32 (6): 957 962.

Bulkeley, H., and Betsill M. M. 2013. "Revisiting the Urban Politics of Climate Change." 
Environmental Politics 22 (1): 136-154.

Caniglia, Beth Schaefer, Robert J. Brulle, and Andrew Szasz. 2015. "Civil Society, Social Movements, and Climate Change." In Climate Change and Society: Sociological Perspectives, edited by Riley E. Dunlap and Robert J. Brulle, 235-268. New York: Oxford University Press.

Castells, Manuel. 2009. Communication Power. Oxford, UK: Oxford University Press. Compston, Hugh. 2009. "Networks, Resources, Political Strategy and Climate Policy." Environmental Politics 18 (5): 727-746.

Crow, Deserai A., and Maxwell T. Boykoff. 2014. "Introduction." In Culture, Politics and Climate Change, edited by Deserai A. Crow and Maxwell T. Boykoff, 1-20. London: Routledge.

Dispensa, Jaclyn Marisa, and Robert J. Brulle. 2003. "Media's Social Construction of Environmental Issues: Focus on Global Warming - A Comparative Case Study." The International Journal of Sociology and Social Policy 23 (10): 74-105.

Dodds, Klaus. 2010. "A Polar Mediterranean? Accessibility, Resources and Sovereignty in the Arctic Ocean." Global Policy 1 (3): 303-311.

Dunlap, Riley E., and Robert J. Brulle. 2015. "Bringing Sociology into Climate Change Research and Climate Change into Sociology." In Climate Change and Society: Sociological Perspectives, edited by Riley E. Dunlap and Robert J. Brulle, 412-436. New York: Oxford University Press.

Dunlap, Riley E., and Aaron M. McCright. 2015. "Challenging Climate Change: The Denial Countermovement." In Climate Change and Society: Sociological Perspectives, edited by Riley E. Dunlap and Robert J. Brulle, 300-332. New York: Oxford University Press. 
Ehrhardt-Martinez, Karen, Thomas K. Rudel, Kari Marie Norgaard, and Jeffrey Broadbent. 2015. "Mitigating Climate Change." In Climate Change and Society: Sociological Perspectives, edited by Riley E. Dunlap and Robert J. Brulle, 199-234. New York: Oxford University Press.

Eide, Elisabeth, and Risto Kunelius. 2012. Media Meets Climate: The Global Challenge for Journalism. Göteborg: Nordicom.

Evans, Suzannah. 2016. "Journalistic Norms, Cultural Values, and Coverage of Climate Change in the Philippines." Environmental Communication 10 (4): 492-507.

Fisher, Dana R., Philip Leifeld, and Yoko Iwaki. 2013. "Mapping the Ideological Networks of American Climate Politics." Climatic Change 116 (3-4): 523-545.

Francesch-Huidobro, Maria. 2012. "Institutional Deficit and Lack of Legitimacy: The Challenges of Climate Change Governance in Hong Kong." Environmental Politics 21 (5): 791-810.

Freudenburg, William R., and Violetta Muselli. 2010. "Global Warming Estimates, Media Expectations, and the Asymmetry of Scientific Challenge." Global Environmental Change 20 (3): 483-491.

Freudenburg, William R., and Violetta Muselli. 2013. "Reexamining Climate Change Debates: Scientific Disagreement or Scientific Certainty Argumentation Methods (SCAMs)?" American Behavioral Scientist 57 (6): 777-795.

Gavin, Neil T. 2009. "Addressing Climate Change: A Media Perspective." Environmental Politics 18 (5): 765-780.

Gavin, Neil T., and Tom Marshall. 2011. "Mediated Climate Change in Britain: Scepticism on the Web and on Television around Copenhagen." Global Environmental Change 21 (3): 1035-1044. 
GlobalChange.gov. 2016. "NOAA Appoints Members to Advisory Committee for the Sustained National Climate Assessment." GlobalChange.gov, June 29. http://www.globalchange.gov/news/noaa-appoints-members-advisory-committee$\underline{\text { sustained-national-climate-assessment }}$

Grundmann, Reiner. 2007. "Climate Change and Knowledge Politics." Environmental Politics 16 (3): 414-432.

Hadden, Jennifer. 2015. Networks in Contention: The Divisive Politics of Climate Change. New York: Cambridge University Press.

Harlan, Sharon L., David N. Pellow, J. Timmons Roberts, Shannon Elizabeth Bell, William G. Holt, and Joane Nagel. 2015. "Climate Justice and Inequality." In Climate Change and Society: Sociological Perspectives, edited by Riley E. Dunlap and Robert J. Brulle, 127163. New York: Oxford University Press.

Hestres, Luis E. 2015. "Climate Change Advocacy Online: Theories of Change, Target Audiences, and Online Strategy." Environmental Politics 24 (2): 193-211.

Ingold, Karin, and Manuel Fischer. 2014. "Drivers of Collaboration to Mitigate Climate Change: An Illustration of Swiss Climate Policy over 15 Years." Global Environmental Change 24: $88-98$.

Jasny, Lorien, Joseph Waggle, and Dana R. Fisher. 2015. "An Empirical Examination of Echo Chambers in US Climate Policy Networks." Nature Climate Change 5 (8): 782-786.

Jordan, Andrew, and Dave Huitema. 2014. "Innovations in Climate Policy: The Politics of Invention, Diffusion, and Evaluation." Environmental Politics 23 (5): 715-734.

Jost, Gestine Foljanty, and Klaus Jacob. 2004. "The Climate Change Policy Network in Germany." European Environment 14 (1): 1-15. 
Lever-Tracy, Constance. 2008. "Global Warming and Sociology." Current Sociology 56 (3): 445-466.

MacGregor, Sherilyn. 2010. "A Stranger Silence Still: The Need for Feminist Social Research on Climate Change." Sociological Review 57 (2): 124-140.

McCright, Aaron M., and Riley E. Dunlap. 2011. "The Politicization of Climate Change and Polarization in the American Public`s Views of Global Warming 2001-2010." The Sociological Quarterly 52 (2): 155-194.

Olausson, Ulrika, and Peter Berglez. 2014. "Media and Climate Change: Four Long-standing Research Challenges Revisited." Environmental Communication 8 (2): 249-265.

Painter, James, and Neil T. Gavin. 2016. "Climate Skepticism in British Newspapers, 20072011." Environmental Communication 10 (4): 432-452.

Perrow, Charles, and Simone Pulver. 2015. "Organizations and Markets." In Climate Change and Society: Sociological Perspectives, edited by Riley E. Dunlap and Robert J. Brulle, 61-92. New York: Oxford University Press.

Richardson, Valerie. 2016. "Democrats' Campaign against Climate Change Skeptics Compared to McCarthyism." Washington Times, July 12. http://www.washingtontimes.com/news/2016/jul/12/web-of-denial-turns-senate-floorinto-democrats-pu/

Roberts, J. Timmons, and Bradley C. Parks. 2007. A Climate of Injustice: Global Inequality, North-South Politics, and Climate Policy. Cambridge: The MIT Press.

Rootes, Christopher, Anthony Zito, and John Barry. 2012. "Climate Change, National Politics and Grassroots Action: An Introduction." Environmental Politics 21 (5): 677-690.

Schäfer, Mike S., and Inga Schlichting. 2014. "Media Representations of Climate Change: A 
Meta-Analysis of the Research Field." Environmental Communication 8 (2): 142-160.

Schmidt, Andreas, Ana Ivanova, and Mike S. Schafer. 2013. "Media Attention for Climate

Change around the World: A Comparative Analysis of Newspaper Coverage in 27

Countries." Global Environmental Change 23 (5): 1233-1248.

Shadian, Jessica M. 2014. The Politics of Arctic Sovereignty: Oil, Ice and Inuit Governance. London: Routledge.

Shwom, Rachel L., Aaron M. McCright, Steven R. Brechin, Riley E. Dunlap, Sandra T. Marquart-Pyatt, and Lawrence C. Hamilton. 2015. "Public Opinion on Climate Change." In Climate Change and Society: Sociological Perspectives, edited by Riley E. Dunlap and Robert J. Brulle, 269-299. New York: Oxford University Press.

Slocum, Rachel. 2004. "Consumer Citizens and the Cities for Climate Protection Campaign." Environment and Planning A 36 (5): 763-782.

Stevenson, Hayley, and John S. Dryzek. 2014. Democratizing Global Climate Governance. Cambridge: Cambridge University Press.

Takahashi, Bruno, and Mark S. Meisner. 2014. "Re-examining the Media-Policy Link: Climate Change and Government Elites in Peru." In Culture, Politics and Climate Change, edited by Deserai A. Crow and Maxwell T. Boykoff, 102-120. London: Routledge.

Tompkins, Emma L., and Helene Amundsen. 2008. "Perceptions of the Effectiveness of the United Nations Framework Convention on Climate Change in Advancing National Action on Climate Change." Environmental Science \& Policy 11 (1): 1-13.

Urry, John. 2011. Climate Change and Society. Cambridge: Polity.

Wejs, A., K. Harvold, S. V. Larsen, and I. L. Saglie. 2014. "Legitimacy Building in Weak Institutional Settings: Climate Change Adaptation at Local Level in Denmark and 
Norway." Environmental Politics 23 (3): 490-508.

Young, Nathan, and Eric Dugas. 2011. "Representations of Climate Change in Canadian National Print Media: The Banalization of Global Warming." Canadian Review of Sociology 48 (1): 1-22.

Young, Nathan, and Eric Dugas. 2012. "Comparing Climate Change Coverage in Canadian English- and French-Language Print Media: Environmental Values, Media Cultures, and the Narration of Global Warming." Canadian Journal of Sociology 37 (1): 25-54.

Zhao, Xiaoquan, Justin Rolfe-Redding, and John E. Kotcher. 2016. "Partisan Differences in the Relationship between Newspaper Coverage and Concern over Global Warming." Public Understanding of Science 25 (5): 543-559. 